\title{
WDCP Gene
}

National Cancer Institute

\section{Source}

National Cancer Institute. WDCP Gene. NCI Thesaurus. Code C101428.

This gene plays a role in binding to tyrosine-protein kinase HCK. 